\title{
INVESTASI ASING DI ACEH SETELAH BERLAKU UU NO. 11 TAHUN 2006
}

\author{
Maryati, B \\ Program Studi Ilmu Hukum, Fakultas Hukum, Universitas Abulyatama, email : \\ maryati_hukum@abulyatama.ac.id
}

\begin{abstract}
The problems associated with conducting research are the extent to which Aceh needs foreign investment in developing its region. The most important question is whether the foreign investment opportunities that exist in Law No. 11 of 2006 can be implemented as desired by the parties. It is also questionable what are the constraints of foreign investment activities in Aceh after the implementation of the Act.This writing uses qualitative descriptive analytical method with emphasis on library research in order to obtain data, in addition also using field research as primary data. The results of the study can be summarized that the main foreign investment opportunities are the existence of peace and security so that all parties including foreign investors are protected from security disturbances. Law Number 11 Year 2006 provides a great opportunity for Aceh to bring in foreign investors, but the Aceh Government does not fully use the opportunity because of a clause limiting the controversial authority with the given authority, which is to comply with prevailing norms, standards and procedures nationally. Constraints impeding foreign investment in Aceh after peace and the realization of security are rules that make investors and operators unimpeded, among others, due to the norms, standards and procedures imposed for foreign investment activities in Aceh as serious obstacles that need to be solved.
\end{abstract}

Keywords : foreign investment, UU No. 11 Tahun 2006, aceh government

\begin{abstract}
Abstrak: Permasalahan yang terkait dengan penyelenggaraan penelitian adalah sejauh mana Aceh membutuhkan investasi asing dalam membangun daerahnya. Yang paling penting dipertanyakan apakah peluang investasi asing yang ada dalam Undang-undang Nomor 11 Tahun 2006 dapat diimplementasikan sebagaimana dikehendaki oleh para pihak. Juga perlu dipertanyakan apa saja kendala dari kegiatan investasi asing di Aceh setelah diimplementasikannya Undang-undang tersebut. Penulisan ini menggunakan metoda analitis deskriptif kualitatif dengan menitik beratkan pada penelitian kepustakaan dalam rangka memperoleh data, di samping juga menggunakan penelitian lapangan sebagai data primer.Hasil penelitian dapat dirangkum bahwa peluang investasi asing yang utama adalah adanya perdamaian dan terciptalah keamanan sehingga semua pihak termasuk investor asing terlindungi dari gangguan keamanan. Undang-undang Nomor 11 Tahun 2006 memberi peluang yang besar bagi Aceh untuk mendatangkan investor asing, akan tetapi Pemerintah Aceh tidak sepenuhnya menggunakan peluang itu karena adanya klausul yang membatasi kewenangan yang kontroversi dengan kewenangan yang diberikan, yaitu keharusan mengikuti norma, standar dan prosedur yang berlaku secara nasional. Kendala yang menghambat investasi asing di Aceh setelah perdamain dan terwujudnya keamanan adalah peraturan yang membuat investor dan penyelenggara tidak leluasa antara lain karena adanya norma, standar dan prosedur yang diberlakukan untuk kegiatan investasi asing di Aceh sebagai hambatan serius yang perlu dicari solusi.
\end{abstract}

\section{Kata kunci : investasi asing, UU No. 11 Tahun 2006, pemerintah aceh}

Investasi asing atau penanaman modal asing di Aceh sudah sejak lama dilaksanakan, sejalan dengan perkembangan dan pembangunan daerah sebagaimana halnya di daerah lain di Indonesia.
Sudah sejak lama dilakukan eksplorasi minyak dan gas di Aceh Timur serta secara besar-besaran di Aceh Utara, dan lebih awal lagi pada tahun 1968 telah ada pengolahan hasil perkebunan kelapa 
sawit dan karet oleh PT Sucfindo Indonesia. Pabrik Semen Andalas di Lhoknga Aceh Besar sebagai investasi asing dalam bentuk joint venture antara beberapa negara didirikan sejak tahun 1980 dan tetap dikembangkan setelah diluluhlantakkan tsunami 26 Desember 2004 karena bahan bakunya masih tersedia dalam kapasitas besar. Berbeda dengan investasi joint venture atas dasar kerja sama regional ASEAN pabrik pupuk Asean Aceh Fertilizer (AAF) di Aceh Utara terpaksa ditutup karena kehabisan bahan bakar gas.

Kerja sama terlaksana dengan baik di Aceh bahkan di masa konflik, sehingga Perusahaan explorasi minyak dan gas dari Amerika Serikat Mobil Oil bersama Pertamina dapat beroperasi tanpa halangan yang berarti. Akan tetapi tentu saja gangguan keamanan di masa konflik dapat saja terjadi meski tidak terhenti operasionalnya terhadap industri yang sudah ada. Sementara itu peluang untuk tumbuh dan berkembang terhambat terhadap investasi asing di Aceh yang tentu saja disebabkan faktor keamanan.

Akan tetapi dengan adanya perjanjian damai antara Republik Indonesia dan Gerakan Aceh Merdeka (GAM) yang melahirkan butir-butir terkait dengan investasi asing dalam MoU Helsinki dan kemudian dijabarkan ke dalam UU No. 11 Tahun 2006 tentang Pemerintahan Aceh, seyogianya iklim investasi menjadi sebuah peluang yang menjanjikan, lebih baik dari masa sebelumnya. Investasi asing di Aceh pada dasarnya harus lebih berkembang dan maju setelah konflik Aceh diselesaikan dengan perdamaian atau ditandatanganinya MoU Helsinki dan diimplementasikannya UU. No. 11 Tahun 2006 karena keduanya ada mengatur tentang investasi asing. Kalau MoU Helsinki menyebutnya dalam butir 1.3.2, maka UU Pemerintahan Aceh mengaturnya dalam pasal 165. Dalam hal itu UU No.25 Tahun 2007 tentang Penanaman Modal juga perlu dikaji karena itulah peraturan utama di samping UU No. 1 Tahun 1967 tentang Penanaman Modal Asing beserta perubahannya serta peraturan lain yang relevan.

Meskipun kran investasi telah dibuka lebar untuk Aceh, namun peluang yang ada dihadapkan dengan hambatan dan kendala dalam realisasinya. Baik tantangan yang ada di lapangan, maupun yang berasal dari Pemerintah Pusat, sehingga apa yang diharapkan dari janji-janji kedua belah pihak dalam kesepakatan damai belum tentu dapat dinikmati.

Berdasarkan latar belakang di atas, maka yang menjadi permasalahan adalah sbb:

1. Sejauh mana Aceh membutuhkan penanaman modal asing dalam membangun daerahnya

2. Apakah peluang investasi asing yang ada sebagaimana tertuang dalam $\mathrm{MoU}$ Helsinki dan UU No 11 Tahun 2006 dapat diimplementasikan sebagaimana mestinya.

3. Apa kendala yang menghambat kegiatan Penanaman Modal Asing di Aceh setelah diimplementasikannya UU No. 11 Tahun 2006 , 


\section{KAJIAN PUSTAKA}

\section{A. Pemahaman Modal Asing dan Penanaman} Modal Asing

\section{Menurut Peraturan Perundangan}

Menurut UU No. 25 Tahun 2007, yang dimaksud dengan Modal Asing adalah modal yang dimiliki oleh negara asing, perseorangan warga negara asing, badan usaha asing, badan hukum asing, dan/atau badan hukum Indonesia yang sebagian modalnya atau seluruhnya dimiliki oleh pihak asing (pasal 1 butir 8). Sementara yang dimaksud dengan modal asing menurut UU No. 1 Tahun 1967 tentang Penanaman Modal Asing adalah sbb : Modal asing adalah alat pembayaran luar negeri yang tidak merupakan bagian dari kekayaan devisa Indonesia, yang dengan persetujuan Pemerintah digunakan untuk pembiayaan perusahaan Indonesia.

UU No. 25 tahun 2007 juga membuat batasan tentang siapa Penanam Modal Asing. Penanaman Modal Asing adalah perseorangan warga negara asing dan/atau pemerintah asing yang melakukan penanaman modal di wilayah negara Republik Indonesia.

\section{Pemahaman Menurut Para Penulis}

Menurut Hulman Panjaitan, Penanaman Modal Asing adalah suatu kegiatan penanaman modal yang di dalamnya terdapat unsur asing (forein element) unsur asing mana ditentukan oleh adanya kewarganegaraan berbeda, asal modal dan sebagainya (Hulman Panjaitan, hal.28). Menurut Komaruddin sebagaimana dikutip Panji Anoraga (Hulman Panjaitan) investasi dimaknai dalam 3 arti, yaitu sebagai suatu tindakan untuk membeli saham, obligasi atau penyertaan lainnya, sebagai suatu tindakan membeli barang-barang modal, dan sebagai pemanfaatan dana yang tersedia untuk produksi dengan pendapatan di masa yang akan datang. Sementara Sumantoro mengatakan bahwa perlu memasukkan loan atau pinjaman luar negeria sebagai bagian dari modal asing (Sumantoro, 92).

\section{B. Teori Mengapa Negara Maju Menanam}

\section{Modal di Negara Berkembang dan} Mengapa Negara Berkembang

\section{Membutuhkan Modal Asing}

Di dalam hasil GATT putaran Uruguay yang dilaksanakan di Marrakesh Maroko tahun 1993, dalam lampiran Trade Related Investmen Measures (TRIMs) mengatur tentang berbagai hal termasuk Penanaman Modal Asing. Namun untuk menjawab mengapa negara maju menanam modal di negara berkembang, lebih dahulu dihadapkan pada dua teori, (Erman Raja Gukguk, dkk hal. 3) yaitu the product cycle theory (teori siklus produk) dan the Industrial organization theory Integration (teori organisasi industri integrasi vertikal).

Menurut the product cycle theory yang dipelopori Raymond Vernon, setiap tehnologi atau produk berevolusi melalui tiga fase, yaitu fase permulaan atau inovasi, fase perkembangan proses, dan fase pematangan. Dalam hal ini fase pertama cendrung bertempat di negara industri paling maju seperti Inggris di abad ke 19 atau Amerika Serikat di abad ke 20. Fase kedua terjadi penyebaran teknologi ke pesaing-pesaing luar negeri yang potensial sehingga diproduksi barang yang sama di luar negeri. Sementara fase ketiga berpindahnya produksi ke negara berkembang yang mempunyai keunggulan komparatif berupa 
tingkat upah yang rendah, untuk kemudian dieksport ke pasaran global.

Sementara teori organisasi industri integrasi vertikal, menyatakan bahwa untuk melakukan bisnis di luar negeri dengan investasi harus mencakup biaya-biaya lain yang harus dipikul oleh perusahaan. Sehingga perusahaan pelaku harus memiliki beberapa keunggulan. Investasi dilakukan dengan cara integrasi vertikal, yakni dengan menempatkan beberapa tahapan produksi di beberapa lokasi yang berbeda di seluruh dunia, sehingga memotivasi diperolehnya keuntungan besar dengan biaya produksi rendah, merintangi pesaing-pesaing dari negara lain dengan tujuan monopoli, memanfaatkan kebijaksanaan pajak lokal, dll.

Selain itu perlu juga dikaji mengapa secara teoritis negara maju menanam modal di negara Indonesia (Erman Rajaguguk, hal.19), yaitu :

1. Karena adanya peraturan/kebijaksanaan yang mendukung investor asing menanam modal di Indonesia

2. Tersedianya tenaga kerja yang besar dengan upah yang relatif rendah

3. Pasar produksi yang luas karena jumlah penduduk yang besar

4. Tersedianya sumber kekayaan alam yang melimpah

5. Adanya stabilitas politik.

Kita juga perlu mengetahui mengapa negara berkembang membutuhkan modal asing. Menurut Chatib Bisri yang ditulis dalam Harian Kompas tanggal 15 April 1993, sebagaimana dikutip Erman Rajagukguk adalah sbb:
1. Keunggulan komparatif suatu negara akan terbuang sia-sia apabila tidak didukung oleh modal yang memadai

2. Karena kebanyakan korporasi bisnis telah meningkat dalam skala global, sehingga negara ketiga harus mengubah kebijakan bersahabat terhadap modal asing

3. Tindakan tertentu dari suatu negara untuk melindungi tujuan nasional dengan cara menutup perusahaan modal asing meskipun memberi manfaat kepada ekonomi domistik tapi menurunnya kesejahteraan secara global.

Akan halnya mengapa negara Indonesia membutuhkan modal asing (Erman Rajaguguk hal. 31) adalah sbb :

1. Untuk meningkatkan potensi ekspors dan subtitusi import, sehingga Indonesia dapat meningkatkan penghasilan devisa dan mampu menghemat devisa, sehingga prioritas dan fasilitas diberikan pada usaha yang bergerak pada peningkatan eksport dan subtitusi import.

2. Agar terjadi alih tehnologi dengan adanya penanaman modal asing sehingga dapat mempercepat lajunya pembangunan nasional.

3. Agar Indonesia dapat melakukan efisiensi perekonomiannya, peningkatan produktifitas, dan perluasan investasi dalam rangka pembangunan nasional. 


\section{Penyelesaian Sengketa Untuk Investasi} Asing

Dalam konteks ini perlu disinggung tentang perusahaan multinasional atau perusahaan transnasional, yaitu perusahaan yang beroperasi dan memiliki cabang di berbagai kawasan dunia. Pada umumnya perusahaan sekaliber inilah yang punya minat besar melakukan ekspansi untuk berinvestasi di negara-negara berkembang. Dalam perkembangannya perusahaan ini menganut paham liberal dalam arti bahwa dengan kehadirannya akan menyebarkan pengembangan dan peningkatan standar kehidupan di seluruh penjuru dunia (Amiruddin Umar, hal. 14-15).

Kalau dikaitkan dengan persoalan kedaulatan negara penerima modal, seyogianya perusahaan multinasional ini menggunakan hukum negara penerima modal jika tidak ada aturan internasional untuk itu. Namun jika aturan internasional ada, maka harus menggunakan aturan internasional, seperti penyelesaian sengketa investasi asing yang diatur oleh International Convention on Setlement and Investment Dispute Beetwen States and nationals of other States (ICSID) atau dikenal juga dengan Konvensi Washington 1958. Konvensi yang terkait erat dengan World Bank ini mengharuskan setiap sengketa diselesaikan dengan arbitrase dan hasil putusannya supaya dapat dieksekusi diatur Konvensi New York 1958, di mana kedua Konvensi tersebut telah diratifikasi Indonesia, sehingga Indonesia terikat untuk mengikuti aturan kedua konvensi tersebut secara "non self executing" atau secara otomatis aturan internasional itu berlaku dan mengikat tanpa perlu pengundangan atau membuat undang-undang nasional baru.
Sangat mungkin sengketa investasi asing timbul di Aceh atau Indonesia. Jalan keluarnya kalau tidak selesai dengan musyawarah, tentu harus mengikuti petunjuk atau aturan kedua konvensi di atas. Tentu saja hal ini tidak akan mengiris kedaulatan, karena hukum internasional itu berlaku secara global. Apalagi terkait teori monisme degan primat Hukum Internasional, artinya hukum internasional itu lebih utama dan lebih tinggi posisinya dari hukun nasional.

\section{INVESTASI ASING DI ACEH SETELAH BERLAKU UU No. 11 TAHUN 2006}

\section{A. Ketentuan Investasi Asing dalam MoU} Helsinki dan UU No. 11 Tahun 2006

Pada dasarnya MoU Helsinki yang menjadi acuan kebijakan setelah Aceh damai hanya menyinggung saja persoalan investasi asing, sebagaimana dicantumkan dalam butir 1.3.2 yang bunyinya sbb : "Aceh berhak menetapkan dan memungut pajak daerah untuk membiayai kegiatan-kegiatan internal yang resmi. Aceh berhak melakukan perdagangan dan bisnis secara internal dan internasional serta menarik investasi dan wisatawan asing secara langsung ke Aceh.”

Menarik wisatawan asing ke Aceh tentu lebih gampang karena tidak memerlukan prosedur yang rumit dibandingkan menarik investasi asing. Akan tetapi menarik investasi memerlukan perangkat hukum dan Jakarta tidak akan semudah membalik tangan membiarkan Aceh terbuka untuk investasi asing tanpa melibatkan peran dominan dari pusat. Namun, apapun bunyi butir MoU Helsinki hanya dapat dilaksanakan kalau sudah dijabarkan dalam undang-undang, dan dalam hal ini telah dijabarkan dalam UU No. 11 Tahun 2006. 
Penjabaran itu tercantum dalam pasal 165 UUPA sebagai berikut :

Ayat (1) : Penduduk di Aceh dapat melakukan perdagangan dan investasi secara internal dan internasional sesuai dengan peraturan perundang-undangan

Ayat (2): Pemerintah Aceh dan Pemerintah Kabupaten/Kota sesuai dengan kewenangannya, dapat menarik wisatawan asing dan memberikan izin yang terkait dengan investasi dalam bentuk penanaman modal dalam negeri, penanaman modal asing, eksport dan import dengan memperhatikan norma standar, dan prosedur yang berlaku secara nasional.

Ayat (3) : Pemerintah Aceh dan pemerintah Kabupaten/Kota sesuai dengan kewenangannya dan berdasarkan norma, standar dan prosedur yang berlaku nasional berhak memberikan :

a. izin eksplorasi dan eksploitasi pertambangan umum

b. izin konversi kawasan hutan

c. izin penangkapan ikan paling jauh 12 mil laut

d. izin penggunaan operasional kapal ikan dalam jenis dan ukuran

e. izin menggunakan air permukaan dan air laut

f. izin yang berkaitan dengan pengelolaan dan pengusahaan hutan

g. izin operator lokal dalam bidang telekomunikasi.

Ayat 2 pasal 165 ini sebagaimana pasal yang lain yang terkait dengan kewenangan mengandung kontroversi. Yaitu disatu pihak memberi peluang yang besar, sehingga seakan UUPA bukan hanya memberi otonomi yang seluas-luasnya kepada Aceh melainkan telah menempatkan Aceh pada level Self Government atau Pemerintahan sendiri sebagaimana dikehendaki MoU Helsinki. Akan tetapi ternyata peluang besar itu kemudian dipangkas melalui keharusan menggunakan norma, standar dan prosedur yang berlaku secara nasional. Artinya ini kembali menempatkan Aceh setara dengan propinsi lain.

Hal di atas tidak sejalan dengan $\mathrm{MoU}$ Helsinki dan bertentangan dengan draf RUUPA yang diajukan rakyat Aceh. Baik draf yang diajukan Civil Society, GAM maupun DPR Aceh yang mengadopsi draf Civil Society maupun draf GAM, di mana peneliti sendiri dahulu terlibat dalam perumusan draf tersebut dan ikut bergabung dalam Jaringan Demokrasi Aceh (JDA) untuk mengawal perumusan di DPR Aceh, terutama perumusan di DPR RI dengan aspirasi mendasari draf DPR Aceh atau draf Rakyat Aceh.

Di dalam UU Pemerintahan Aceh bukan hanya pasal ini saja mengalami diskualifikasi kewenangan, akan tetapi ada beberapa pasal yang kesemuanya mengacu kepada norma, standar, dan prosedur nasional yang menyebabkan kekhususan untuk Aceh menjadi tidak jelas.

Bukan hanya terdapat kesenjangan besar antara MoU Helsinki dan UU Pemerintahan Aceh, akan tetapi kesenjangan itu diperkuat lagi dengan gamblang dalam PP Kewenangan Aceh sebagai peraturan pelaksana UUPA. Sebelumnya RPP Kewenangan lama mengambang tidak disahkan hingga habis masa jabatan Presiden SBY. 
Pertengahan 2015 Presiden Jokowi mensahkannya, akan tetapi pasal yang menghela Aceh tak berbeda dengan propinsi lain dalam hal kewenangan tetap dipertahankan. Mungkin merasa dikhianati atau disepelekan pihak berkompeten di Aceh menurut seorang staf ahli Kepala Pemerintahan Aceh, pasal-pasal kontroversi itu akan direvisi.

Peluang yang ada dalam pasal 165 UU No. 11 Tahun 2006 adalah memberi akses bagi Aceh untuk menyelenggarakan penanaman modal asing dengan tidak menunggu proses dari pusat, akan tetapi menarik sendiri atau menawarkan langsung.

\section{B. Peluang dalam UU Penanaman Modal} (UU No. 25 Tahun 2007)

Kalau di dalam UU Penanaman Modal (UU No. 25 Tahun 2007), peluang dari Investasi baik nasional maupun asing dapat dilihat pada asas dan tujuan serta fasilitas. Apa yang dicantumkan dalam Pasal 3 ayat $1 \quad(b, d, g)$ yaitu asas keterbukaan, perlakuan yang sama dan tidak membedakan asal negara, kebersamaan, berkelanjutan, dan ayat 2 (b,c,g,h) menciptakan lapangan kerja, meningkatkan ekonomi berkelanjutan, mengolah ekonomi potensial menjadi kekuatan ekonomi riil dengan menggunakan dana yang berasal dari dalam negeri maupun luar negeri. Juga fasilitas yang diberikan sebagaimana dicantumkan dalam pasal 18 ayat 2 $(a, b)$ fasilitas diberikan kepada penanam modal yang melakukan perluasan usaha, melakukan penanaman modal baru dan ayat 3 .

Peluang lain ada dalam pasal 22, ayat 1 (a,b,c) dengan memperbaharui masa penggunaan hak atas tanah, yaitu 35 tahun untuk Hak Guna
Usaha (HGU), 30 tahun untuk Hak Guna Bangunan (HGB) dan 25 tahun untuk Hak Pakai, dari masing-masing hak atas tanah yang diberikan dan diperpanjang dimuka sekaligus, yaitu 60 tahun untuk HGU, 50 tahun untuk HGB dan 45 tahun untuk Hak Pakai. Sehingga keseluruhan hak atas tanah yang dapat digunakan untuk HGU, HGB, dan Hak Pakai adalah 95, 80, dan 70 tahun.

Peluang dalam UU Penanaman Modal dinikmati oleh seluruh propinsi di Indonesia. Hanya saja kita akan melihat adakah peluang ini mendapat tempat khusus untuk Aceh, mengingat hasil perjanjian damai yang tertuang dalam butir 1.1.2 MoU Helsinki yang bunyinya sbb : a) Aceh akan melaksanakan kewenangan dalam semua sektor publik, yang akan diselenggarakan bersamaan dengan administrasi sipil dan peradilan, kecuali dalam bidang hubungan luar negeri, pertahanan luar, keamanan nasional, hal ikhwal moneter dan fiskal, kekuasaan kehakiman, dan kebebasan beragama, di mana kebijakan tersebut merupakan kewenangan Pemerintah Republik Indonesia sesuai dengan Kontitusi.

Terkait dengan investasi asing di Aceh tentu perlu dipertanyakan sejauh mana kaitannya dengan hubungan luar negeri. Memang urusan penyelenggaraan investasi asing adalah urusan dengan pihak asing, akan tetpi bukanlah urusan politik, melainkan perdagangan. Untuk itu dapat dikaitkan dengan pasal 165 ayat 2 yang menegaskan bahwa Pemerintah Aceh dapat memberi izin untuk penanaman modal dalam negeri dan juga penanaman modal asing. Jadi tak perlu dipertanyakan lagi bahwa kewenangan di bidang investasi asing adalah kewenangan Pemerintah Aceh. Pemerintah dapat memberi izin 
dan juga dapat mengundang modal asing ke Aceh, dengan catatan terikat dengan norma, standar dan prosedur yang berlaku. Tentu saja hal ini mengingatkan Pemerintah Aceh bahwa dalam kewenangan yang diberikan ada pembatasan yang harus dihiraukan dan dipatuhi.

\section{Mengapa Aceh Membutuhkan}

\section{Investasi Asing}

Apabila pihak asing telah mengeksplorasi dan mengeksploitasi seluruh sumber daya alam, tentu rugi besar jika hanya menguntungkan pihak investor sementara masyarakat sekitar gigit jari. Akan tetapi apabila sumber daya alam melimpah sementara tidak ada yang mengolah atau tidak mampu mengolah atau tidak ada modal untuk itu, maka kedatangan pihak asing untuk melakukan investasi baik investasi langsung maupun kerja sama patungan baik dalam bentuk joint venture atau joint enterprise, atau bentuk kerja sama lainnya sangat dibutuhkan. Yang penting, alih tehnologi terjadi dengan sebaik-baiknya, sehingga knowledge dan skill beralih kepada negara penerima modal sebagaimana diharapkan.

Aceh memiliki sumber daya alam melimpah, baik di daratan maupun lautan. Sayangnya investasi asing yang dilakukan selama ini kurang memperhatikan tenaga kerja lokal sehingga memicu timbulnya gejolak. Sementara kebutuhan Aceh akan modal asing bukan semata untuk kepentingan Pemerintah Pusat. Akan tetapi bagaimana tenaga kerja Aceh bisa terserap dan alih tehnologi terjadi secara maksimal.

Tanpa modal asing Aceh akan pincang menyelenggarakan perekonomiannya karena keterbatasan tenaga skill dan modal. Sebagai contoh rencana pemanfatan Geothermal untuk energi pembangkit tenaga listrik di Seulawah oleh investor Jerman. Rencana investasi asing tidak tentu rimbanya, sementara Pemerintah RI belum mampu melakukan sendiri, apalagi pemerintah Aceh. Artinya Aceh memang membutuhkan modal asing dan kebutuhan itu sejalan dengan apa yang disampaikan Erman Rajagukguk di atas terkait dengan mengapa negara berkembang membutuhkan modal asing (lihat Erman Rajagukguk). Kebutuhan itu juga terkait dengan kebutuhan mengeksplorasi sumber daya alam seperti gothermal tersebut, atau untuk mengembangkan terminal minyak internasional seperti pernah dicanangkan di Pulau Aceh yang menuai protes. Eksplorasi dan eksploitasi sumber daya alam yang membutuhkan skill yang tinggi dan tak dapat dilaksanakan oleh investor lokal atau nasional itu tentu membutuhkan investor asing. Ketergantungan Aceh akan tenaga listrik yang terus tergantung pada listrik di daerah lain misalnya, mengandung kerawanan, karena menghadapi berbagai kendala. Berbeda dengan investasi di bidang perkebunan seperti kelapa sawit, yang masih mungkin dikerjakan oleh putra daerah meski dengan areal terbatas, yang selama ini sebagian telah pula menjadi upaya kegiatan dalam rangka reintegrasi anggota GAM, adalah suatu solusi permasalan politik dengan mengacu pada penanganan persoalan ekonomi. Kalau semua mantan kombatan GAM bersedia membuka lahan untuk perkebunan sawit seperti itu, maka solusi permasalahan reintegrasi banyak yang terjawab dan perdamaian akan lebih kokoh (Interview 
dengan eks Perunding GAM, petengahan Desember 2016). Ada baiknya investasi asing bidang pertambangan misalnya harus bisa diolah dan menghasilkan barang jadi di Aceh, seperti pada pertambangan Lhong Setya Mining (LSM) yang menambang pasir besi di Lhong Aceh Besar agar dapat memberi kesempatan kerja bagi tenaga kerja sekitar (arahan Wali Nanggroe Aceh dalam berbagai pidato sambutan). Sebaliknya investor asal Tiongkok itu mengangkut begitu saja pasir yang diambil untuk diolah di negara mareka.

\section{METODE PENELITIAN}

Penelitian ini adalah penelitian kualitatif, yang dilakukan melalui pengamatan dan wawancara. Peneliti mewawancarai narasumber yang relevan dengan materi yang sedang dikaji disertai observasi yang seksama. Data sekunder terdiri dari surat-surat pribadi, buku harian, notulen rapat, sampai dokumen-dokumen resmi dari berbagai instansi pemerintah.

\section{HASIL DAN PEMBAHASAN}

\section{Peluang dan Perkembangan Investasi Asing}

di Aceh.

Penanaman modal asing di Aceh yang telah dimulai sejak zaman kolonial pernah mengalami pasang surut. Artinya adakalanya investasi asing itu meningkat dan adakalanya jalan ditempat dari tahun ke tahun. Untuk itu perlu ditampilkan data akurat tentang pasang surut tersebut bedasarkan fakta yang ada, yang telah dirangkum oleh pihak Badan Investasi dan Promosi yang dahulu bernama Badan Koordinsi Penanaman Modal Daerah (BKPMD). Badan inilah yang mengontrol pelaksanaan penanaman modal, baik dalam negeri maupun asing dan bersinergi dengan Badan Koordinasi dengan BKPM di Pusat.

Tabel 1. Data Perkembangan Penanaman Modal Asing di Aceh tahun 1968-2014

\begin{tabular}{|c|c|c|c|c|}
\hline NO & TAHUN & $\begin{array}{l}\text { JUMLAH } \\
\text { INVES. }\end{array}$ & $\begin{array}{l}\text { JUMLAH } \\
\text { BIDANG } \\
\text { INVESTASI }\end{array}$ & $\begin{array}{l}\text { REALISASI } \\
\text { MODAL } \\
\text { (US DOLAR) }\end{array}$ \\
\hline 1. & 1968 & 1 & 1 & 23.161 .000 \\
\hline 2. & 1980 & 1 & 1 & 200.088 .000 \\
\hline 3. & 1981 & 1 & 1 & 14.888 .000 \\
\hline 4. & 1986 & 1 & 1 & 14.060 .548 \\
\hline 5. & 1987 & 1 & 1 & - \\
\hline 6. & 1990 & 1 & 1 & - \\
\hline 7. & 1994 & 2 & 2 & 1.800 .000 \\
\hline 8. & 1996 & 2 & 2 & 444.803 .226 \\
\hline 9 & 1997 & 1 & 1 & 286.272 .000 \\
\hline 10. & 1998 & 2 & 2 & 1.984 .602 \\
\hline 11 & 2000 & 2 & 2 & 15.648319 \\
\hline 12. & 2001 & 1 & 1 & - \\
\hline 13. & 2004 & 1 & 1 & 5.000 \\
\hline 14. & 2005 & 3 & 3 & - \\
\hline 15. & 2006 & 1 & 1 & 188.571 \\
\hline 16. & 2007 & 6 & 6 & 291.820 .741 \\
\hline 17. & 2008 & 20 & 13 & 445.721 .476 \\
\hline 18. & 2009 & 24 & 19 & 159.081 .792 \\
\hline 19. & 2010 & 32 & 21 & 8.678 .805 \\
\hline 20. & 2011 & 29 & 19 & 318.444 .789 \\
\hline 21. & 2012 & 20 & 15 & $107.841,9$ \\
\hline 22. & 2013 & 14 & 11 & $975.726,6$ \\
\hline \multirow[t]{2}{*}{23} & 2014 & 18 & 14 & $2.099 .112,6$. \\
\hline & Jumlah & 182 & & \\
\hline
\end{tabular}

Sumber Data : Badan Investasi dan Promosi Aceh

Tabel di atas menggambarkan bahwa penanaman modal asing di Aceh mengalami maju mundur. Sebelum konflik berkecamuk hebat yang melanda seluruh Aceh setelah fakum 2 tahun melonjak naik nilai uang yang diinvestasi meski hanya 2 perusahaan yang menanam modal, yaitu tahun 1996 dan 1997. Kemudian menurun. Bahkan disaat konflik memuncak, tahun 2001, 2002 dan 2003 investasi asing menghilang sama sekali hingga tahun menjelang tsunami saat konflik tak menentu dan menjelang perdamaian investasi hanya ada dalam rencana saja. Setelah penandatangan MoU Helsinki, Agustus tahun 2005, di tahun 2006 PMA kembali bergeliat, dan setahun kemudin mulai melaju dengan 5 investasi. Tahun 2008 investasi asing menanjak menjadi 20 
buah dengan nilai tertinggi sepanjang investasi asing dilakukan di Aceh. Dari segi kuantitas terus melaju hingga mencapai investasi terbanyak dari segi jumlah investor, meski kemudian menurun drastis secara kualitatif atau jumlah modal yang diinvestasi. Perkembangan terakhir sebelum penelitian ini dilaksanakan, tahun 2014 data kembali meningkat baik dari jumlah investor maupun nilai uang yang diinvestasi.

Adakalanya rencana para investor atau penanam modal tidaklah berjalan sebagaimana direncanakan. Yakni jumlah yang dapat direalisasikan berkurang dari direncanakan. Tentu saja ini karena terhalang oleh beberapa kendala, baik dari investor sendiri maupun dari Pemerintah Indonesia, dalam hal ini Pemerintah Pusat.

Adapun peluang investasi atau penanaman modal asing pada dasarnya terbuka lebar dan meningkat setelah penandatanganan perdamaian Aceh, lebih-lebih setelah diimplementasikannya UU No. 11 Tahun 2006 terutama secara kuantitas atau jumlah investor. Hal ini terlihat pada tabel di atas. Akan tetapi kemudian mengalami penurunan setelah memuncak terutama secara kualitatif atau jumlah modal yang diinvestasi oleh para investor asing itu. Kemudian tidak semua perusahaan investasi asing itu aktif beroperasi, hingga tahun 2012 terdapat 62 perusahaan investasi asing menjadi tidak aktif, hingga akhir 2012. Tidak aktifnya atau vakumnya sebuah perusahaan investasi asing tentu punya latar belakang sendiri. Ada kendala atau hambatan untuk terus melaksanakan kegiatan atau beroperasi. Kalau bukan bangkrut tentu dihambat oleh peraturan yang ada yang tidak memihak perusahaan itu.
Dari tabel yang tersedia terlihat bahwa perdamaian atau situsasi keamanan di Aceh menjadi peluang utama bagi investor untuk menanam modal di Aceh. Di samping itu faktor alam dengan kandungan melimpah juga menjadi daya tarik nutama sebagaimana dikemukan oieh staf Badan Investasi dan Promosi Aceh (Wawancara akhir November 2016) dan 3 investor asing yang beroperasi di Banda Aceh, (diinterview awal Desember 2016).

\section{Hambatan Pada Investasi Asing di Aceh}

Kelihatannya hambatan utama investasi asing di Aceh adalah keamanan, sehingga terlihat makin tinggi eskalasi konflik makin kurang atau tidak ada minat investor untuk menanam modal di Aceh. Setelah konflik reda jumlah investor meningkat drastis, sepertinya mareka tidak lagi mementingkan kualitas atau jumlah investasi yang besar, akan tetapi kecilpun jadi.

Di masa awal perdamaian mengapa investor berlomba-lomba datang ke Aceh sehingga mencapai jumlah yang mengejutkan meskipun dengan nilai investasi kecil, adalah karena mareka memiliki persepsi, banyak kemudahan dan fasilitas tersedia di Aceh dengan adanya MoU Helsinki yang menjadikan Aceh sebagai sebuah Self Government seperti yang dipraktekkan di Alan Island Finlandia, Jeju Korea Selatan, dll. Ternyata setelah mareka melakukan kegiatan investasi apa yang mareka perkirakan ada yang sangat istimewa di Aceh dalam kenyataannya Aceh terikat dengan apa yang dinamakan dengan norma, standar dan prosedur yang sama dengan wilayah lain di Indonesia.

Proses perizinan dari Pemerintah pusat tetap 
ada dan terkadang rumit sebagaimana dikehendaki oleh peraturan perundangan khususnya pasal 165 UU Pemerintah Aceh. Jadi perizinan bukanlah milik rakyat dan Pemerintah Aceh, kecuali dalam hal tertentu. Mungkin berbeda dengan daerah lain menyangkut dengan peluang yang tidak di atur dengan undang-undang khusus, jadi jelas semua sangat tergantung ada Pemerintah Pusat. Di Aceh peluang berubah menjadi hambatan, karena terdapat kontroversi Pemerintah Aceh terhadap induk yang menelorkannya yaitu MoU Helsinki, sehingga setelah UU yang dijabarkan dari Kesepakatan Damai itu diimplementasikan, keadaan tetap status quo, selama belum ada revisi terhadap pasal terkait dalam UU dimaksud. Supaya masalah tereliminir maka revisi itu harus dilakukan.

\section{KESIMPULAN DAN SARAN}

\section{Kesimpulan}

1. Peluang investasi yang paling utama di Aceh adalah perdamaian, karena dengan perdamaian dan berakhirnya konflik, terciptalah keamanan dan semua pihak merasa terlindungi dari gangguan termasuk pihak investor asing

2. Pada dasarnya UU No 11 Tahun 2006 telah memberi peluang yang besar bagi Aceh untuk mendatangkan investor asing, akan tetapi pihak Pemerintah Aceh tak dapat sepenuhnya menggunakan peluang itu karena adanya klausul yang membatasi kewenangan Pemerintah Aceh yang kontroversi dengan kewenangan yang diberikan yaitu dengan adanya keharusan Pemerintah Aceh mengikuti norma, standar dan prosedur yang berlaku secara nasional.

3. Kendala yang menghambat investasi asing di Aceh setelah persoalan keamanan tertangani adalah peraturan yang membuat investor dan penyelenggara tidak leluasa, yaitu persoalan norma, standar dan prosedur yang diberlakukan untuk kegiatan investasi asing di Aceh sebagaimana tercantum dalam UU Pemerintahan Aceh dan hal inilah yang menjadi hambatan serius.

\section{Saran-Saran}

1. Agar Pemerintah Aceh dengan didukung rakyat mengajukan revisi pasal-pasal UU No. 11 Tahun 2006 dan PPnya yang memuat persyaratan morma, standar dan prosedur dalam menerapkan suatu kebijakan agar kewenangan Pemerintah Aceh bukan hanya semu belaka.

2. Agar Pemerintah Pusat memberi peluang kepada Pemerintah Aceh agar melaksanakan janji-janji dalam Undang-Undang Pemerintah Aceh terkait dengan bagi hasil yang menguntungkan Aceh dapat direalisasikan secara realistis termasuk yang terkait dengan investasi asing.

\section{DAFTAR PUSTAKA}

Amiruddin Ilmar. (2007). Hukum Penanaman Modal di Indonesia, Cetakan ke 3. Jakarta: Putra Grafika.

Hulman Panjaitan. (2003). Hukum Penanaman Modal Asing, IND-HILL-CO, Jakarta.

Ismail Sunny. (1984). Undang-Undang PMA dan Kredit Luar Negeri. Jakarta: Pradnya Paramita.

Munir Fuadi. (1994). Hukum Bisnis dalam 
Teori dan Praktek. Bandung: PT Citra Adytia Bakti.

Pemerintah Aceh. (2012). Perkembangan Penanaman Modal Tahun 2012. Banda Aceh: Badan Investasi dan Promosi Aceh

Sumantoro (1986). Hukum Ekonomi, Jakarta: Universitas Indonesia (UI Press). 